\title{
USING STRUCTURAL EQUATION MODELING APPROACH TO INVESTIGATE FARMERS' PERCEPTION CONSEQUENCES OF DROUGHT (CASE STUDY: BIRJAND TOWNSHIP, IRAN)
}

\author{
Hosseini, S. M. ${ }^{1}-$ RoOsta, K. ${ }^{1 *}-$ ZAMANIPOUR, A. $^{1}-$ TEYMOURI, M. ${ }^{2}$ \\ ${ }^{I}$ Department of Agricultural Extension and Education, Birjand Branch, \\ Islamic Azad University, Birjand, Iran \\ (phone: +98-9-120-338-909; fax: +98-5-632-213-146) \\ ${ }^{2}$ Department of Rural Development, Science and Research Branch, \\ Islamic Azad University, Tehran, Iran \\ (phone: +98-9-159-611-216; fax: +98-2-188-442-210) \\ *Corresponding author \\ e-mail: roosta_kuroush@yahoo.com; phone: +98-9-120-338-909; fax: +98-5-632-213-146
}

(Received $9^{\text {th }}$ May 2017; accepted $4^{\text {th }}$ Dec 2017)

\begin{abstract}
As a natural disaster and inevitable phenomenon, droughts are frequently seen in vast areas of different countries, particularly in areas with hot and dry climates. It has resulted in heavy economic, social, and environmental losses. Undoubtedly, the first step to cope with droughts and their consequences is to have an accurate understanding of droughts and their effects on different aspects by specifying the related strategies and approaches in this regard. Given the importance of this issue, the present study was conducted to investigate how to model farmers' perception of consequences of drought through structural equation modeling in Birjand Township, Iran. All farmer households living in rural areas of Birjand (a city in the Iranian province of Southern Khorasan) composed the statistical population of this study ( $\mathrm{N}=6057)$. As many as 200 households were chosen for the study by using Bartlett's table. In total, 20 villages were considered as the target districts using stratified random sampling. The results showed that the most important consequences of droughts understood by the farmers are their economic (0.341), environmental $(0.261)$, and social $(0.138)$ consequences. The highest indirect effects on the farmers' perception of consequences of drought in Birjand were: reduced income (0.286), increased bank debts (0.272), reduced purchasing power (0.265), and the wells, aqueducts and springs that have dried $(0.224)$ respectively. In this regard, measures such as supporting the investment and entrepreneurship, granting banking facilities and credits, governmental oversight on water withdrawals from groundwater sources, development of infrastructures and irrigation and water supply networks, reuse of wastewater, identification and promotion of products compatible with saline and unconventional waters, development of support services and social security for rural communities and development and promotion of drought insurance are proposed in order to reduce the consequences of drought.
\end{abstract}

Keywords: drought, consequences of drought, structural equation modeling, farmers' perception, Birjand Township

\section{Introduction}

Most recently, the phenomenon of drought, its intensity, frequency and duration have drawn many concerns around the world (Sivakumar et al, 2014; Peterson et al., 2013). This phenomenon is constantly paid attention rather than a natural phenomenon due to reasons like a constantly growing population, its intangible and long-term impacts, and the duration and severity of damages (Rezaei et al., 2010). Droughts are natural hazards threatening human life and the natural ecosystems (Jamshidi, 2014). Droughts lead to dwindling surface and underground water sources and thereby lead to multiple negative effects in all aspects of rural life-especially in economic and agricultural structures. 
Droughts and the resultant shortage of water leading to declining agricultural production have become major global concerns these days (Liu et al., 2008). Although this crisis is not considered as a new phenomenon for farmers, the complexity of the contributing factors and the interweaving of the negative impact of droughts make these a main concern of farmers living in areas with critical situations (Campbell et al., 2011). In addition, frequent droughts have made rural communities more vulnerable (Speranza et al., 2008) in such a way that many rural communities try to survive in the face of a drought (Campbell et al., 2011). Iran has experienced the problem of water shortage and droughts in the past two decades, with its regions and provinces being more or less affected. According to a report of the National Drought Warning and Monitoring Center, the Southern Khorasan ranks third when it comes to facing the onslaught of droughts (National Drought Warning and Monitoring Center, 2016). Owing to recent droughts, 905 villages in this province have been suffering from scarcity of water. The extent of damages to the agricultural sector due to such droughts was over $\$ 375 \mathrm{~m}$ during the years 2014-2015 (Agricultural Jihad Organization of Southern Khorasan, 2016). These are just a few instances of damage and consequences of drought in Southern Khorasan. The comprehensive identification of the effects of drought can play a very effective role in the formulation of policies and strategies to deal with such a natural disaster. Besides, without any knowledge of farmers' attitude to drought, the probability of the success of formulated plans for drought management and dealing with its consequences will be very poor. Therefore, the main question of this study is: What are farmers' perspectives on consequences of drought in Birjand Township?

\section{Review of the literature}

Droughts imply deviations from normal or medium conditions of precipitation; they are seen when the precipitation is less than $75 \%$ of the average precipitation in a region over a period (usually 25-30 years) (Wilhite, 1993). In general, a drought could be defined as a situation of shortage of rainfall and increased temperature that may occur at any climatic conditions (Alizadeh, 2002). This phenomenon disturbs vital water systems and thus creates high risks for the region (Kaviani and Alijani, 1999); it is one of the most persistent and pernicious economic disasters that is believed to stem from a complex mechanism, and its nature is less well-known than other natural disasters (Javanmard et al., 2000). This phenomenon forms a group of effects that occur in various aspects and are visible gradually over a long period following the occurrence. Diverse perspectives are discussed in this regard-some of these classify the effects of drought into direct and indirect or primary and secondary categories (Wilhite, 1993; Kardavani, 2001). Direct effects of drought are often associated with climate and ecological characteristics, while the indirect effects are subtler and related to economic and social damages that can be barely distinguished due to their nature and features (Wilhite, 1996).

Droughts are counted among major Iranian climate characteristics, and these can be seen in both wet and dry conditions. The characteristics of a drought in Iran show that any region of the country has suffered this event and its destructive effects (Nasaji Zavareh, 2001). Undoubtedly, drought involves a mental picture of barren lands, destroyed crops, and survival efforts for most people. Therefore, a change in the weather pattern is expected, along with a disruption of daily activities, in the event of a drought. The effects of drought can be divided into economic, social, and environmental 
impacts (Eskandari and Mosayebi, 2008). Reduction of the area for cultivation of crops, reduction of the fertility of pastures and forests, increases in fire incidents, dwindling underground water levels, increasing mortality rate of livestock, and increasing damage to wildlife and habitats of fish are argued to be some of the direct effects of this phenomenon. The decline in production and area under cultivation of crops could reduce the revenue of farmers and workers in this sector, raise food prices, increase unemployment, decrease tax revenues, and increase crimes and lawsuits relating to legal problems due to delay in repayment of bank loans and facilities are also known as indirect effects of drought (Saleh and Mokhtari, 2007; Jamshidi, 2014). Several studies have been conducted on droughts and their effects on human communities in domestic and foreign territories of Iran. Some of these works are discussed here.

Nasaji Zavareh (2001) recognized the most important economic consequences of drought in the form of declining income for farmers and workers, increasing input prices, rising unemployment and immigration, decreasing agricultural land values, and increasing food prices. Mohammadi Yeganeh and Hakimdoust (2009) concluded that droughts in multi-year time scales negatively impacted agricultural and rural economy, altered the function of rural land, and reduced the income and employment opportunities for villagers. Moreover, Alimoradi (2009) argued that the drought of Ilam Province had increased from the southwestern part to the northeastern in 2007-2008 and had resulted in reduction of the discharge capacity of rivers and underground water level of alluvial aquifers. Beikmohammadi et al., (2005) showed that Sistan had experienced a profoundly negative impact on the rural economy in both agriculture and animal husbandry sections because of the drought of 1998-2004. Furthermore, Sharafi and Zarafshani (2011), in a comparative study, elucidated that wheat farmers in Rawansar Township were the most vulnerable against droughts, while wheat farmers in Kermanshah Township dealt with the lowest socio-economic vulnerability.

Holden and Shiferaw (2004) indicated that the indirect effect of drought on family welfare through its effects on prices of livestock and crops was greater than those of direct impact. Sivakumar et al. (2005) believed that agricultural productivity in Asian tropical regions not only increased the temperature, but also was sensitive to the altered nature and characteristics of monsoon showers. The simulation of climate change showed that the changes increased the frequency of droughts, the greatest risk for farmers.

Kenny (2008) considered physical and mental stress, anxiety, depression, family conflicts, reduced quality of life, increased immigration, and increasing poverty as the social consequences of droughts. Gentle and Maraseni (2012) suggested that climate changes could influence such components as livelihoods, food security, and increasing poverty and social inequality in Nepal. Antwi-Agyei et al. (2012) found that climate change and droughts in Ghana had the strongest effect on the agriculture section in terms of the vulnerability of crops. Ayinde et al. (2011) studied the effect of climate change on agricultural productivity in Nigeria; they revealed that changes in climate, particularly in the pattern of rainfall, had a significant impact on the agricultural productivity. Lilleor and van den Broeck (2011) believed that environmental changes, along with economic and social factors, provided the conditions for immigration. Baba et al. (2011) demonstrated large-scale immigration of the global population and thereby portrayed political and economic crises, poverty, and starvation caused by the reduction in of agricultural land resources, the intense decline in biodiversity due to the incompatibility of some species to adapt to new climatic conditions, and increased morbidity and mortality as results of climate change. Schilling et al. (2012) had shown 


$$
-524-
$$

that the Moroccan economy and poor people were strongly dependent on the agricultural sector, while climate change and droughts probably had the strongest effect on this sector.

\section{Materials and methods}

\section{Introduction of the studied area}

Birjand Township is the capital of Southern Khorasan province, which is the third biggest province of Iran in terms of area $\left(150800 \mathrm{~km}^{2}\right.$, equal to $9.15 \%$ of the entire area of the country) and is located in $59^{\circ} 13^{\prime} \mathrm{E}$ and $32^{\circ} 53^{\prime} \mathrm{N}$. (Fig. 1). Since it is situated on a dry and semidry climatic belt, far from sea, adjacent to desert regions, and exposed to the 120-day peripheral winds of Sistan, this township has always been subject to drought (Khosravi and Akbari, 2009).

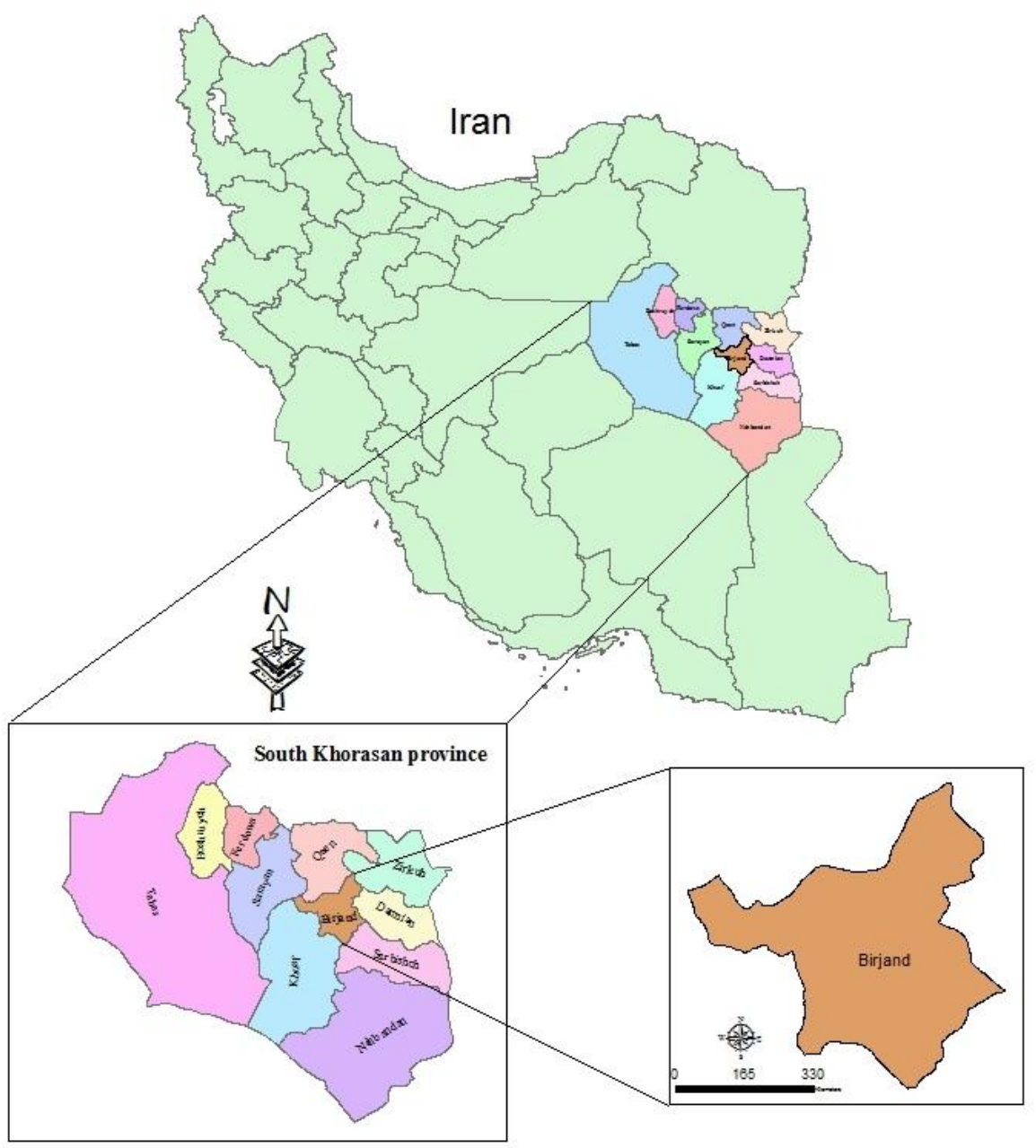

Figure 1. The location of study area in Birjand, Southern Khorasan province, Iran

The average precipitation of the Birjand Township is equal to $151.6 \mathrm{~mm}$, i.e. around half of the average precipitation of the country and one-fifth of the global average. Ombrothermic diagram, designing monthly mean of temperatures and precipitation 
data, as well as time series analysis of changes in precipitation within a 30 year period indicates a descending trend with a relatively sharp slope, clearly indicating the critical status of precipitation and provision of water resources of the Birjand Township throughout this period (Fig. 2, 3). This has caused incidence of frequent droughts across the township: in a 30 year period, it has experienced 15 years of drought (National Drought Warning and Monitoring Center, 2016).

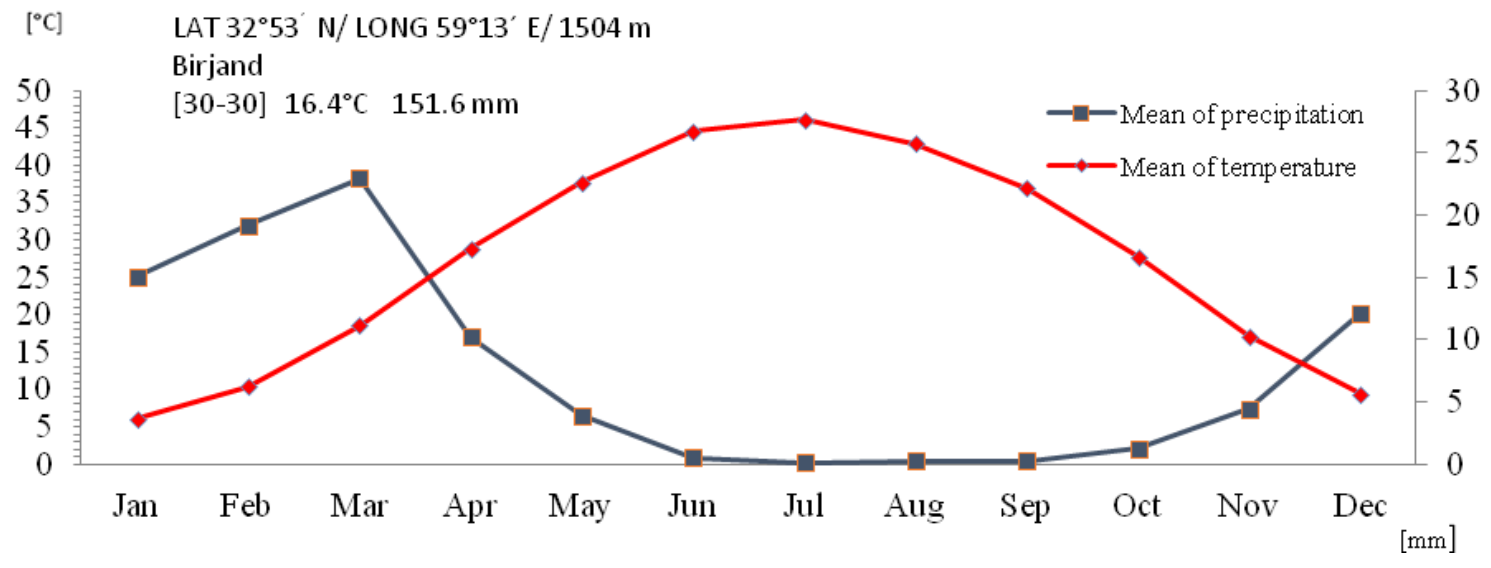

Figure 2. Ombrothermic diagram from monthly mean temperatures and precipitation data collected by the Birjand meteorological station (1987-2016).

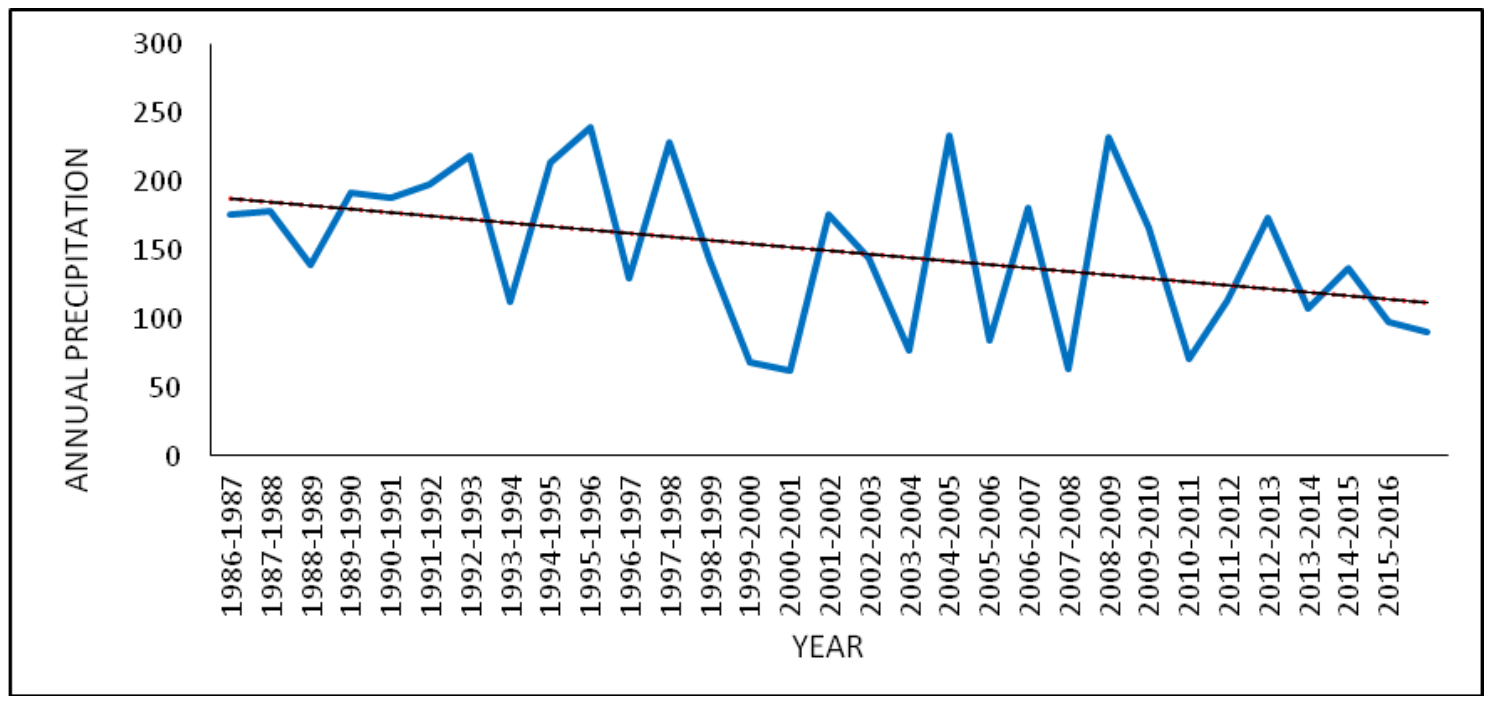

Figure 3. Time series of changes in precipitation in Birjand Township within the a 30 year period

\section{Methodology}

This study is an applied research study; it is a descriptive-analytical work aided by the data collection method, which was carried out based on structural equation modeling (SEM). The statistical population of this study was composed of all farmer households living in rural areas of Birjand Township in Southern Khorasan Province of Iran 
( $\mathrm{N}=6057)$ who were influenced by droughts during the years 2006-2015 (farmers engaged in agricultural activity in the region for at least the past 10 years and have faced droughts in the region). To determine the sample size, 2016 census data was used in accordance with which 6,057 farmer households work in rural areas of the studied township. As many as 200 households were selected as samples using Bartlett's table (2001). In total, 20 villages were considered as the target using a stratified random sampling process (districts were as the study classes).

Data collection tools in this study was provided by a questionnaire including queries in two parts in such a way that the former contains personal and professional characteristics of farmers including age, gender, level of education, history of agricultural activity, with the latter encompassing some items about farmers' perception of economic (eight items), social (eight items), and environmental consequences of drought (eight items) as well as their perspectives (attitude) on drought (10 items). SEM was used for data analysis in the Amos Graphics software. SEM mainly focuses on the hidden (latent) variables that have been defined by markers or observed variables (Rezaei, 2013). Content validity and construct validity were used to determine the validity of the research tools. Content validity was validated using the comments of university faculty members. Moreover, composite reliability was used to assess the reliability of instruments.

\section{Results}

\section{Descriptive results}

Most of the respondents (59\%) stated that $100 \%$ of household income is to be derived from agricultural activities. As many as $87.5 \%$ of the people surveyed represented farming as their main job, while $62.6 \%$ were employed only in farming. The average age of respondents was 49 years with a standard deviation of 12; the youngest and the oldest farmers were aged 25 and 72 years. In total, $22 \%$ of the farmers were illiterate, $21 \%$ had an elementary level of education, $14 \%$ had a degree of guidance school, 28\% had high school degree/diploma, and 15\% had higher qualification than diploma. The access to agricultural service centers was at a moderate or high level for about $68 \%$ of the respondents.

\section{Structural equation}

\section{Checking the status of indicators (observed variables)}

Table 1 contains a summary of descriptive statistics (mean and standard deviation) components of the farmers' perception of consequences of drought and the initial validity of each of the factors considered based on Cronbach's alpha coefficient.

\section{Confirmatory factor analysis and assessing validity of scales}

To create and test the validity of the three subscales, including social, economic, and environmental effects as influencing factors on the perception of consequences of drought in Birjand Township, three single-factor confirmatory factor analysis (CFA) models were drawn and analyzed in the Amos Graphics platform.

The results of measuring the adjusted model (first-order confirmatory factor analysis) on the basis of standardized coefficients showed that the items increased input prices and production costs, lowered the value of rural assets, and caused disruption in trade 
(economic consequences) and loss of the quality of agricultural land, destructed animal habitats and wildlife in the area, reduced the variety and quality of plant species in the area (environmental consequences), increased insecurity and crime, reduced aid and cooperation among villagers, and lowered human values and disorder of beliefs (social consequences). These were related to the independent latent variables and some items like "there is no way to deal with drought and must be surrendered to fate, with the drought it is better to leave the villages by producers" (farmers perspective of the consequences of drought) were related to the dependent variable (latent) that were excluded from the measurement model due to lower factor loading 0.5. Factor loadings of other variables were greater than 0.5. Also, the results in Table 1 show, the values of average variance extracted (AVE) for three hidden factors are higher than 0.5. In addition to these two indicators, the results showed that the composite reliability values obtained for the factors evaluated in the measurement model, higher than 0.7 (Table 1). In general, given the results obtained based on these three criteria, the research tools can be concluded to have a suitable convergent validity (a high internal convergence among the studied items). Regarding the reliability of the present study, since the composite reliability values obtained for the diverse (latent) hidden variables were greater than 0.7 , it can be noted that the survey instrument enjoys an adequate reliability.

As can be seen in Table 2, the measurement model has goodness of fit and logical relationships are established between variables.

The fitting indices used in Table 2 including normed chi-square $\left(\mathrm{X}^{2} / \mathrm{df}\right)$, incremental fit index (IFI), root mean square residual (RMR), comparative fit index (CFI), goodness of fit index (GFI), parsimony ratio (PRATIO) and root mean square error of approximation (RMSEA) are the criteria to verify the formulized theoretical models by using the field data collected in the present study.

\section{The second-order three-factor confirmatory factor analysis model for latent variable} analysis of farmers' perception of consequences of drought

After carrying out the first-order confirmatory factor analysis, the second-order confirmatory factor analysis model was used in this section to understand the casual effects of our conceptual models and to assess the significance of the impact of the main latent variables. This model was also used to rank these variables according to their effects on forming and articulating farmers' perception of droughts in rural communities of Birjand. In doing so, the results of the second-order analysis are presented in Figure 4 and Tables 3 and 4 . The standard path coefficients between the latent variables and each other, along with the observed variables and the latent variables, which, in fact, are the most important and main portion of our analysis, can be seen in Figure 4.

The correlation coefficients between the farmers' perception of consequences of drought in Birjand rural communities and the three components of economic consequences, environmental consequences, and social consequences were derived as $0.341,0.261$, and 0.138 respectively. Moreover, the results of standard error estimations, critical ratios, and significance levels show that all these standard estimates are significant at a level of $99 \%$. The obtained final model-fitting indices, along with standard values for their evaluation, are presented in Table 3. Table 4 presents the standardized regression coefficients (direct and indirect effects) for the final observed variables and the obtained subscales on the main latent dependent variable. 
Table 1. Description of items and observed indicators (final variables) of the subscales affecting the perception of the consequences of drought

\begin{tabular}{|c|c|c|c|c|c|c|c|c|c|c|}
\hline \multicolumn{2}{|c|}{$\begin{array}{l}\text { Subscales affecting } \\
\text { perception of the } \\
\text { consequences of } \\
\text { drought }\end{array}$} & Items & 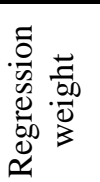 & 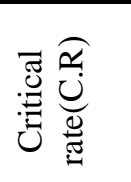 & 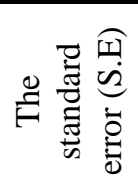 & 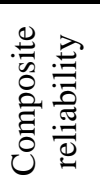 & 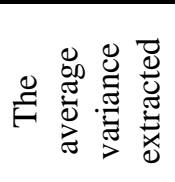 & $\stackrel{\Xi}{\stackrel{\Xi}{E}}$ & 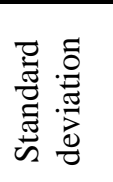 & 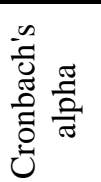 \\
\hline & E.C1 & Reduced purchasing power & 1 & & & & & 3.36 & 1.17 & \\
\hline $\mathscr{e}_{0}^{2}$ & E.C2 & Reduced revenue & 0.896 & $5.238^{* * *}$ & 0.171 & & & 3.38 & 1.23 & \\
\hline 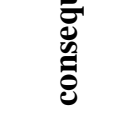 & E.C3 & $\begin{array}{l}\text { Reduced incentive to invest due to } \\
\text { increased risk }\end{array}$ & 0.936 & $4.589^{* * * *}$ & 0.204 & 0.786 & 0.765 & 3.34 & 1.3 & 0.851 \\
\hline 弟 & E.C4 & Increased debt to the banks & 0.477 & $5.238^{* * *}$ & 0.091 & & & 3.23 & 1.14 & \\
\hline$\underset{0}{\tilde{0}}$ & E.C5 & $\begin{array}{l}\text { Low wages and lack of } \\
\text { employment areas }\end{array}$ & 0.626 & $5.741^{* * * *}$ & 0.109 & & & 3.23 & 1.22 & \\
\hline & En.C1 & Dried wells, aqueducts and springs & 1 & & & & & 3.75 & 0.911 & \\
\hline & En.C2 & $\begin{array}{c}\text { Reduced quality of water } \\
\text { resources }\end{array}$ & 0.288 & $4.434^{* * *}$ & 0.065 & & & 3.24 & 0.948 & \\
\hline 忥 & En.C3 & $\begin{array}{l}\text { Reduced surface and groundwater } \\
\text { resources }\end{array}$ & 0.586 & $6.892^{* * *}$ & 0.085 & 0.798 & 0.693 & 3.18 & 1.29 & 0.809 \\
\hline |ี & En.C4 & Soil erosion and desertification & 0.894 & $7.451^{* * * *}$ & 0.12 & & & 3.65 & 1.01 & \\
\hline & En.C5 & Pests and diseases & 0.587 & $6.525^{* * *}$ & 0.09 & & & 3.42 & 0.732 & \\
\hline 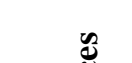 & S.C1 & Resorting to false and illegal jobs & 1 & & & & & 3.46 & 1.02 & \\
\hline 矛 & S.C2 & Mental and emotional tensions & 0.648 & $4.533^{* * *}$ & 0.143 & 0.812 & 0.713 & 3.51 & 0.885 & 0.791 \\
\hline ๘ & S.C3 & $\begin{array}{c}\text { Increased migration of villagers to } \\
\text { cities }\end{array}$ & 0.892 & $8.035^{* * * *}$ & 0.111 & & & 3.32 & 1.09 & \\
\hline
\end{tabular}




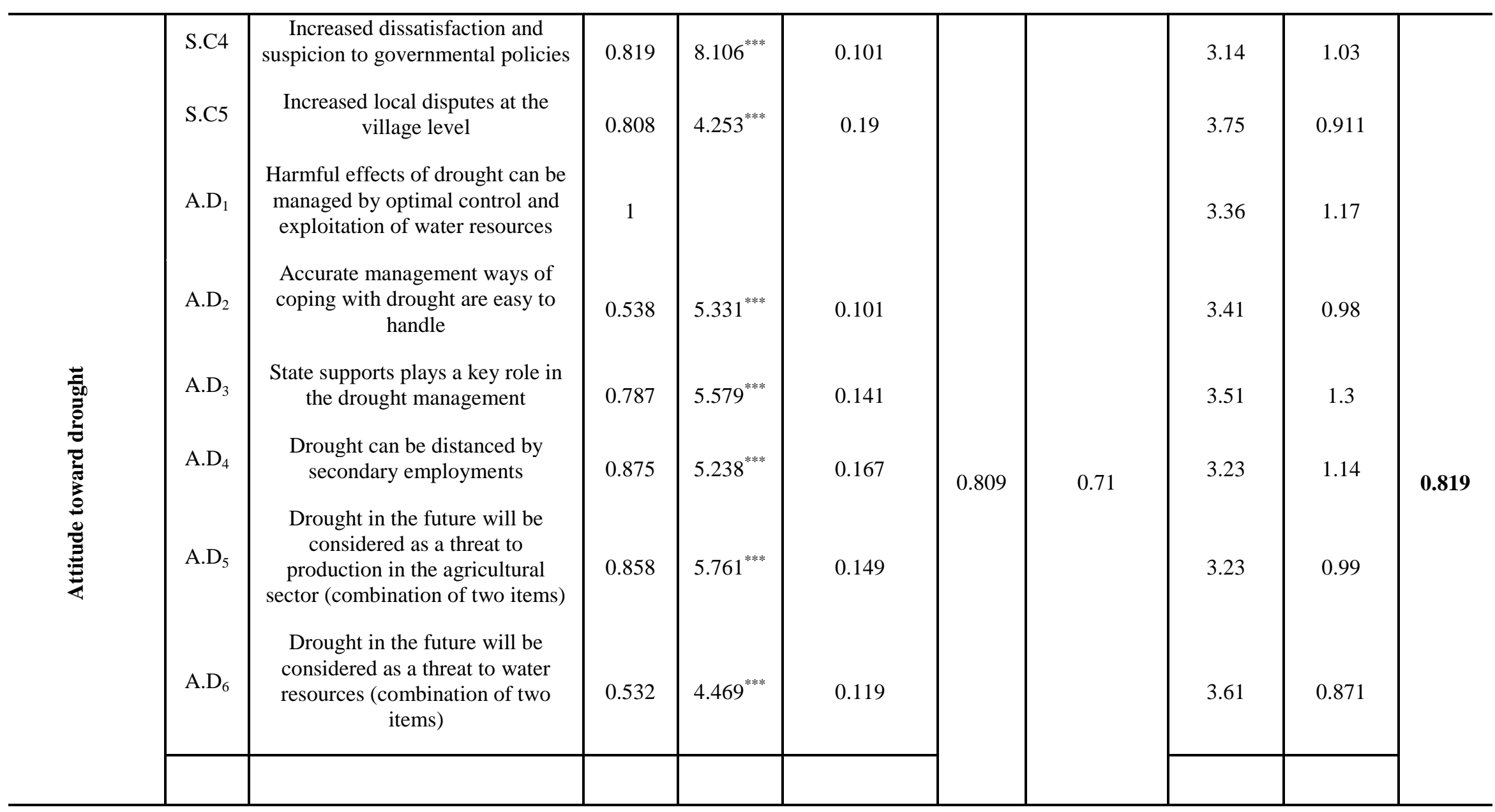

Source: research findings, 2016. ns: non-significant, * confidence level of 95\%, ** confidence level of 99\%*** error of 0.001 


$$
-530-
$$

Table 2. Compliance of the measurement model with fitting indices

\begin{tabular}{c|c|c|c|c|c|c|c}
\hline Indexes & $\mathbf{X}^{2} / \mathbf{d f}$ & IFI & RMR & CFI & GFI & PRATIO & RMSEA \\
\hline $\begin{array}{c}\text { Proposed criterion * } \\
\text { The reported value for } \\
\text { measurement model } \\
\text { Economic consequences** } \\
\text { The reported value for } \\
\text { measurement model } \\
\begin{array}{c}\text { Environmental } \\
\text { consequences** }\end{array}\end{array}$ & 2.28 & $0.9 \leq$ & $\leq 0.08$ & $0.9 \leq$ & $0.9 \leq$ & $0-1$ & $\leq 0.08$ \\
$\begin{array}{c}\text { The reported value for } \\
\text { measurement model } \\
\text { Social consequences** } \\
\text { The reported value for } \\
\text { measurement model } \\
\text { Farmers' attitude** }\end{array}$ & 2.619 & 0.975 & 0.98 & 0.915 & 0.74 & 0.07 \\
\hline
\end{tabular}

Source: * Ghasemi, 2010; ** findings, 2016

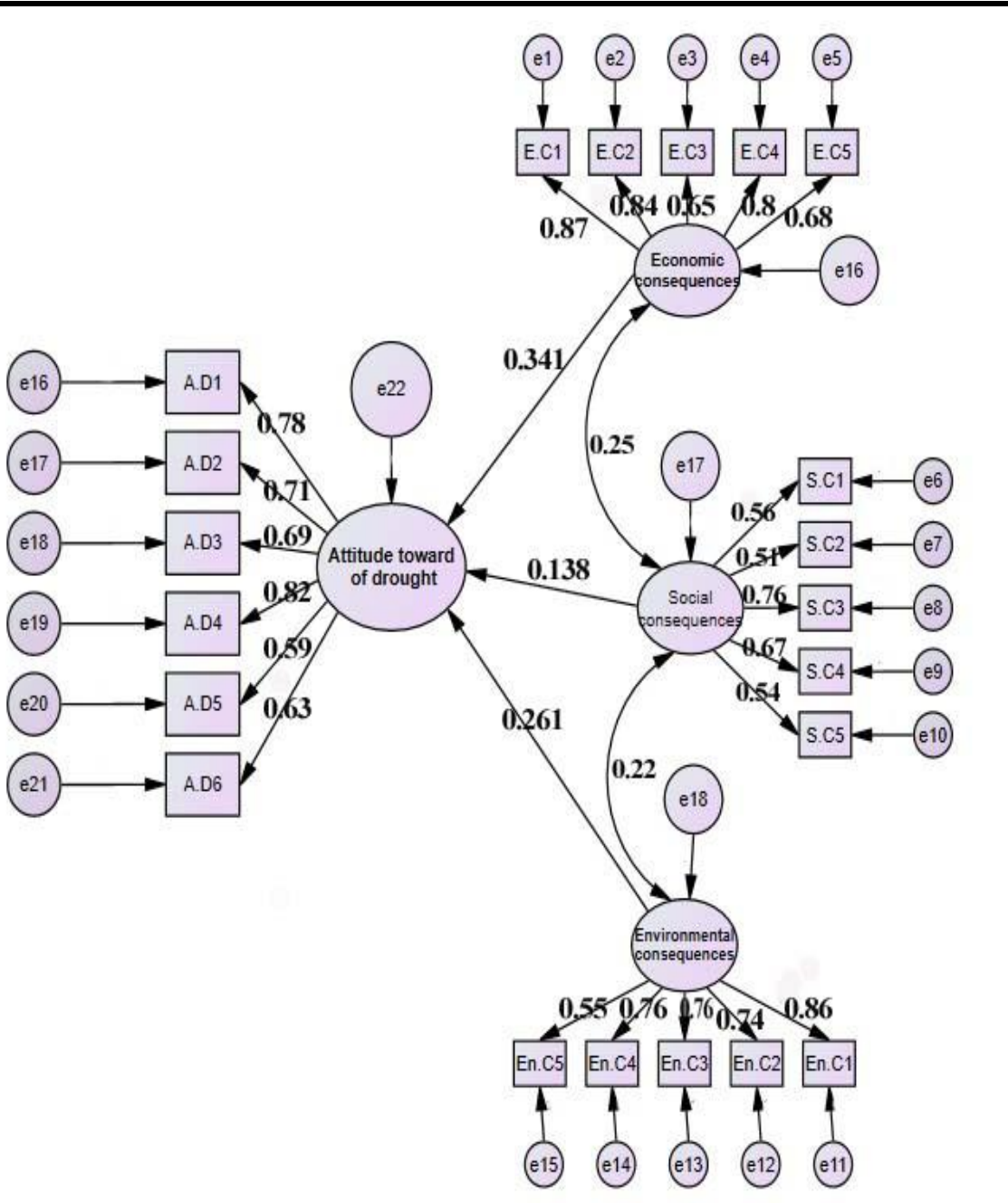

Figure 4. The second-order three-factor confirmatory factor analysis model for latent variable analysis of farmers' perception toward the three components of economic, environmental, and social consequences 


$$
-531-
$$

Table 3. The results of the compliance of the structural model with fit indices

\begin{tabular}{c|c|c|c|c|c|c|c}
\hline Indexes & $\mathbf{X}^{2} / \mathbf{d f}$ & IFI & RMR & CFI & GFI & PRATIO & RMSEA \\
\hline $\begin{array}{c}\text { Proposed criterion } \\
*\end{array}$ & $\leq 3$ & $0.9 \leq$ & $\leq 0.08$ & $0.9 \leq$ & $0.9 \leq$ & $0-1$ & $\leq 0.08$ \\
Reported value** & 2.05 & 0.91 & 0.067 & 0.97 & 0.945 & 0.81 & 0.065 \\
\hline
\end{tabular}

Source: * Ghasemi, 2010; ** findings, 2016

The results of Table 4 show that the highest indirect effects on the farmers' perception of consequences of drought (economic, social, and environmental consequences) in Birjand Township are related to variables such as reduced revenue (E.C2), increased debt to banks (E.C4), reduced purchasing power (E.C1) and dried wells, and aqueducts and springs (En.C4), while the lowest ones are concerned with mental and emotional tensions (S.C2), increased local disputes at the village level (S.C5), and resorting to false and illegal jobs (S.C1). Owing to these coefficients, the lowest and highest impacts are associated social and economic consequences respectively.

Table 4. Overall effects of the observed variables and the subscales on the evaluation of the farmers' perception of consequences of drought

\begin{tabular}{|c|c|c|c|c|}
\hline & $\begin{array}{c}\begin{array}{c}\text { Evaluation of farmers' } \\
\text { perception of } \\
\text { consequences of } \\
\text { drought }\end{array} \\
\end{array}$ & $\begin{array}{c}\text { Economic } \\
\text { consequences }\end{array}$ & $\begin{array}{l}\text { Environmental } \\
\text { consequences }\end{array}$ & $\begin{array}{c}\text { Social } \\
\text { consequences }\end{array}$ \\
\hline $\begin{array}{c}\text { Economic } \\
\text { consequences }\end{array}$ & 0.341 & - & - & 0.25 \\
\hline $\begin{array}{c}\text { Environmental } \\
\text { consequences }\end{array}$ & 0.261 & - & - & 0.22 \\
\hline Social consequences & 0.138 & 0.25 & 0.22 & - \\
\hline E.C1 & 0.265 & 0.87 & - & - \\
\hline E.C2 & 0.286 & 0.84 & - & - \\
\hline E.C3 & 0.221 & 0.65 & - & - \\
\hline E.C4 & 0.272 & 0.8 & - & - \\
\hline E.C5 & 0.208 & 0.68 & - & - \\
\hline En.C1 & 0.224 & - & 0.86 & - \\
\hline En.C2 & 0.193 & - & 0.74 & - \\
\hline En.C3 & 0.2 & - & 0.769 & - \\
\hline En.C4 & 0.198 & - & 0.76 & - \\
\hline En.C5 & 0.143 & - & 0.55 & - \\
\hline S.C1 & 0.077 & - & - & 0.56 \\
\hline S.C2 & 0.07 & - & - & 0.51 \\
\hline S.C3 & 0.104 & - & - & 0.76 \\
\hline S.C4 & 0.092 & - & - & 0.67 \\
\hline S.C5 & 0.074 & - & - & 0.54 \\
\hline A. $D_{1}$ & 0.78 & - & - & - \\
\hline A. $D_{2}$ & 0.71 & - & - & - \\
\hline A.D 3 & 0.69 & - & - & - \\
\hline A. $D_{4}$ & 0.82 & - & - & - \\
\hline A. $D_{5}$ & 0.59 & - & - & - \\
\hline A. $D_{6}$ & 0.63 & - & - & - \\
\hline
\end{tabular}




\section{Discussion}

The present study was conducted to investigate farmers' perception of consequences of drought in Birjand by using structural equation modeling, followed by a review and description of the most important results. Based on the findings, droughts have a direct negative impact on production of crops and livestock as well as an indirect impact on the incentive to invest due to the increased risk and decreased fields of employment in the agricultural sector. These have resulted in reduced revenue and consequently a lower purchasing power for farmers- the concepts which clearly appeared in present work. This finding is in line with the work of Singh et al. (2014). Therefore, given the considerable decline in rural incomes, it makes sense to adopt such approaches and policies as payment of subsidies and supporting the investment and entrepreneurship among the regions affected by drought to create employment and income, restore rural livelihoods and create small and early-return workshops in villages, development and support of production of handicrafts like carpets, rug, and jajim (woolen cloth), which were traditional craft in Southern Khorasan rural regions, and generally, allowing for activities that would pave the way for the restoration of rural incomes.

Based on our findings, the lowered value of rural assets and increased debt to the bank are concepts extracted by the results of the present study. This finding is consistent with Bostani et al. (2015). The convenience granting of diverse, sufficient, low-interest, and gratuitous banking facilities and credits and extension of agricultural loans repayment can be fruitful efforts to reduce the mentioned damages.

The results have shown that continuous droughts in recent years have dwindled surface and groundwater resources, thereby drying and reducing the quality of their water resources. The use of such water, in turn, lowers the quality of agricultural land in such a way that some salt-sensitive products are no more arable in these lands. This finding is in line with the work of Panda et al. (2007). Some of the strategies that can reduce the undesirable consequences of droughts in the region are governmental oversight on water withdrawals from groundwater sources, controlled withdrawals from wells by installing smart meters, effective water-pricing policies, prevention of digging of new wells, development of infrastructures and irrigation and water supply networks compatible with local conditions, reuse of wastewater, and restoration of returned waters into the cycle of consumption, and identification and promotion of products compatible with saline and unconventional waters.

Livelihoods of rural households affect many social relations and interactions; these have forced villagers willing to take up illegal jobs. Economic problems and the disruption of many of the relationships and social interactions have provided an unsuitable and unsafe environment for villagers. Consequently, many rural families were forced to migrate to towns and cities with the hope of obtaining better working conditions and providing welfare for their families. This result is in line with the work of Shewmake (2008). Some effective actions to reduce such damages include development of support services and social security for rural communities, development and promotion of drought insurance, and creating appropriate legal institutions and authorities for conflict resolution regarding the use of water and pasture. 


$$
-533-
$$

\section{REFERENCES}

[1] Agricultural Jihad Organization of Southern Khorasan. (2016): Agricultural statistics of Southern Khorasan. - Iranian Ministry of Agriculture Jihad, Iran.

[2] Alimoradi, S. (2009): Investigation of the effects of drought in 2007-2008 on water resources in Ilam province and proposed solutions to mitigate the effects of drought. 2nd National conference on the effects of drought and its management solutions, University of Isfahan, Iran.

[3] Alizade, A. (2002): Applied principles of hydrology. - AQR Publishing, Mashhad.

[4] Antwi-Agyei, P., Fraser, E. D. G., Dougill, A. J., Stringer, L. C., Simelton, E. (2012): Mapping the vulnerability of crop production to drought in Ghana using rainfall, yield and socioeconomic data. - Applied Geography 32: 324-334.

[5] Ayinde, O. E., Muchie, M., Olatunji, G. B. (2011): Effect of climate change on agricultural productivity in Nigeria: A Co-integration model approach. - Journal of Human Ecology 35(3): 189-194.

[6] Baba, A., Tayfur, G., Gündüz, O., Howard, K. W. F., Friedel, M. J., Chambel, A. (2011): Climate change and its effects on water resources - Issues of national and global security. - Springer, Available at the following URL, http://trove.nla.gov.au/work/157753352.

[7] Beikmohammadi, H., Noori, H. A., Bazrafshan, J. (2005): Effects of drought in 19982009 on the rural economy of Sistan and solutions to comfort it. - Journal of Geography and Improvement 3: 53-72.

[8] Bostani, A., Najafpour, B., Javani, K. (2015): Analysis the effects of drought on rural settlements instability in Drab Villages Township. - Journal of Zonal Planning 6: 155165 .

[9] Campbell, D., Barker, D., McGregor, D. (2011): Dealing with drought: Small farmers and environmental hazards in southern St: Elizabeth, Jamaica. - Applied Geography 31(1): 146-158.

[10] Eskandari, N., Mosayebi, M. (2008): Drought and its effects on natural resources. Technical report, Natural Resources, Forests, Range and Watershed Management Organization, Iranian Ministry of Agriculture Jihad, Tehran, Iran.

[11] Gentle, P., Maraseni, T. N. (2012): Climate change, poverty and livelihoods: adaptation practices by rural mountain communities in Nepal. - Journal of Environmental Science and Policy 21: 24-34.

[12] Holden, S., Shiferaw, B. (2004): Land degradation, drought and food security in a lessfavoured area in the Ethiopian highlands: A bio-economic model with market imperfection. - Agricultural Economics 30(1): 31-49.

[13] Jamshidi, M. (2014): Assessment of drought impacts on the socio-economic structure of agricultural based rural areas (Case study: Sirvan and Chardavol Townships). - Ph.D. Dissertation, Department of geography and rural planning, University of Isfahan, Iran.

[14] Javanmard, S., Bazrafshn, J., Javdani, N. (2000): Care system to the extent Palmer drought index based on zoning. - Journal of the National Center for Climatology 4: 1-11.

[15] Kardavani, P. (2001): Drought and ways to cope with it in Iran. - Tehran University Publishing, Tehran.

[16] Kaviani, M. R., Alijani, B. (1999): Hydro-meteorological principles. - Samt Publishing, Tehran.

[17] Kenny, A. (2008): Assessment of the social impacts of drought. - Journal of American Water Resources Association 37: 678-686.

[18] Khosravi, M., Akbari, M. (2009). Investigation of the drought characteristics of Southern Khorasan province. - Geography and Development 14: 51-68.

[19] Lilleor, H. B., Van den Broeck, K. (2011): Economic drivers of migration and climate change in LDCs. - Global Environmental Change 21: 70-81. 
[20] Liu, C., Golding, D., Gong, G. (2008): Farmers' coping response to the low flows in the lower Yellow River: A case study of temporal dimension of vulnerability. - Global Environmental Change 18(4): 543-553.

[21] Mohammadi Yeganeh, B., Hakimdoust, Y. (2009): The economic impact of the drought and its impact on rural instability in the Zanjan province (Case study: Ghareposhtlo Village). - 1st Regional conference on water crisis and drought, University of Rasht, Iran.

[22] Nasaji Zavareh, M. (2001): Investigate of the economic, social and environmental effects of drought. - 1st National conference on water crisis, University of Zabol, Iran.

[23] National Drought Warning and Monitoring Center. (2016): The final report of drought in provinces and towns. - Available at the following URL, http://ndwmc.irimo.ir/.

[24] Panda, D. K., Mishra, A., Jena, S. K., James, B. K., Kumar, A. (2007): The influence of drought and anthropogenic effects on groundwater levels in Orissa, India. - Journal of Hydrology 343(3-4):140-153.

[25] Peterson, T. C., Hoerling, M. P., Stott, P. A., Herring, S. C. (2013): Explaining extreme events of 2012 from a climate perspective. - American Meteorological Society 94(9): S1S74.

[26] Rezaei, A., Hosseini, M., Sharifi, O. (2010): Analyze and explain the impact of drought on rural city of Zanjan (Case study: Hajarash Village). - Rural Research 14(1): 18-30.

[27] Rezaei, R. (2013): Designing the measurement model of students' satisfaction with library of agricultural faculty in University of Zanjan using confirmatory factor analysis. Library and Information Science 16(4): 6-26.

[28] Saleh, I., Mokhtari, D. (2007): The effects of the economic and social impact of drought on rural households in Sistan region. - Iranian Agricultural Extension and Education 3(1): 123-135.

[29] Schilling, J., Freier, K. P., Hertig, E., Scheffran, J. (2012): Climate change, vulnerability and adaptation in North Africa with focus on Morocco. - Agriculture, Ecosystems and Environment 156: 12-26.

[30] Sharafi, L., Zarafshani, K. (2011): Assessment of the economic and social vulnerability against the drought (Case study: Wheat farmers Kermanshah, Sahne and Ravansar Townships). - Journal of Rural Research 4: 129-154.

[31] Shewmake, S. H. (2008): Vulnerability and the impact of climate change in South Africa's Limpopo River Basin. - International Food Policy Research Institute, Available at the following URL, http://www.ifpri.org/publication/vulnerability-and-impact-climatechange-south-africas-limpopo-river-basin.

[32] Singh, N. P., Bantilan, C., Byjesh, K. (2014): Vulnerability and policy relevance to drought in the semi-arid tropics of Asia - A retrospective analysis. - Weather and Climate Extremes 3: 54-61.

[33] Sivakumar, M. V. K., Stefanski, R., Bazza, M., Zelaya, S., Wilhite, D. A., Magallhaes, R. (2014): High-level meeting on national drought policy: Summary and major outcomes. Weather and Climate Extremes 3: 126-132.

[34] Sivakumar, M. V. K., Das, H. P., Brunini, O. (2005): Impact of present and future climate variability and change on agriculture and forestry in the arid and semi-arid tropics. Climate Change 70: 31-72.

[35] Speranza, C. I., Kiteme, B., Wiesmann, U. (2008): Droughts and famines: The underlying factors and the causal links among agro-pastoral households in semi-arid Makueni district, Kenya. - Global Environmental Change 18: 220-233.

[36] Wilhite, D. A. (1996): Drought: a global assessment. - Routledge Publishing, UK.

[37] Wilhite, D. (1993): Understanding the phenomenon of drought. - Hydro-Review 12(5): 136-148. 